ISSN 2658-4824 (Print)

DOI: 10.33779/2658-4824.2020.3.056-067

\title{
Interview with Composer Marcus Paus Conducted for ICONI by Edward Green
}

W e learn in this interview with the leading Norwegian composer of his generation, Marcus Paus (b. 1979), how critical he is of the "academic tradition" which, in his view, has hurt a good deal of contemporary music over the last several decades: a certain snobbish adherence to non-tonal, non-melodic "abstract modernism." Paus, on the contrary, asserts the living freshness of traditional values. His own music is grounded in tradition, is steeped in the value of careful craftsmanship, and yet, at the same time, is passionate, surprising, original, deeply lyrical, and fervently humanist in its social and political orientation. We learn, too, of his great esteem for the American composer John Williams, best known for his cinematic scores. Paus sees Williams as a model of nobility: both musically, and as a human being. In this interview there is also substantial discussion of the value of the philosophy of Aesthetic Realism, founded by the great American philosopher Eli Siegel, and his profound ideas concerning Art and Life. During this wide-ranging conversation, Paus speaks likewise of world music, pop music, and his abiding interest in literature and painting. There is also an extended passage where he keenly and generously comments on the composers of his own generation, and points to several of their most outstanding works.

Из этого интервью с ведущим норвежским композитором своего поколения Маркусом Паусом (1979 года рождения) мы узнаем, насколько критически он относится к «академической традиции», которая, по его мнению, несколько по-

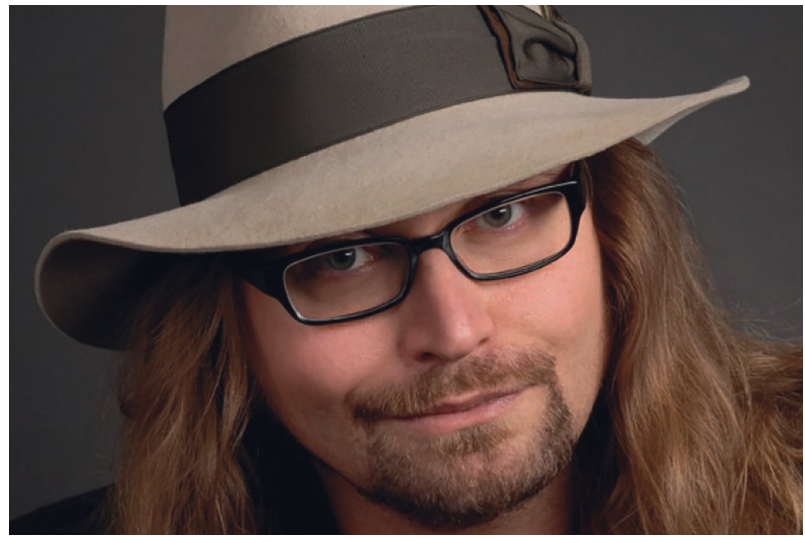

Photo 1. Marcus Paus

[photo credit: Norskmusikforlag]

следних десятилетий наносила вред современной музыке некой снобистской приверженностью нетональному, немелодичному «абстрактному модернизму». Паус, напротив, утверждает свежесть жизни традиционных ценностей. Его собственная музыка основана на традициях, пропитана ценностью тщательного мастерства и, в то же время, эмоциональна, наделена неожиданными поворотами, оригинальна, глубоко лирична и пылко гуманистична в своей социальной и политической ориентации. Мы также узнаем о его глубоком почитании американского композитора Джона Уильямса, наиболее известного своими музыкальными сочинениями к фильмам. Паус видит в Уильямсе образец благородства как в музыкальном плане, так и в человеческом. В этом интервью также широко обсуждается ценность эстетического реализма, основанного великим американским философом Эли Сигелем, и его глубокие идеи, касающиеся искусства и жизни. Во время этого 
разговора, охватившего широкий диапазон тем, Паус также говорит о мировой музыке, поп-музыке и своём неизменном интересе к литературе и живописи. Есть в интервью и фрагмент, в котором он с воодушевлением щедро комментирует композиторов своего поколения и указывает на их наиболее выдающиеся произведения.

Edward Green: When I think of your work, you seem to have taken a different direction than that of most other concert composers of your generation. That is: you have an ease with earlier musical traditions, and a love for them, that stands out as central to your personality as a composer. I think of Verdi's famous statement, "Let's go back to old ways; it will be progress" - which surprised just about everyone at that time. And, of course, I don't mean (nor did Verdi) a mechanical repetition of earlier ways of doing melody, rhythm, harmony, etc. - but a fresh inspiration from them, a relish in them. Am I right about this? If so, I'd imagine you'd have points of agreement not only with Verdi, but also - more recently - with a person like George Rochberg. Or with Prokofiev, who made that lovely statement: "There are still so many beautiful things to be said in C major." Can you comment on all this?

Marcus Paus: When I was accepted to the composition program at the Norwegian Academy of Music, the fundamentals of my technical approach to writing were already somewhat cemented. Much to the chagrin of some of my professors there! At the academy, the climate was distinctly "contemporary," which is to say largely Eurocentric and modernist, and back then (this was the late 1990s), the pursuit of a melodically driven, tonally centered contemporary music was seen as patently misguided.

Edward Green: Yes; I remember those times. It was seen almost as a "contradiction in terms.”

Marcus Paus: Indeed.

Edward Green: And trust me: it was even worse in the late 60s and early 70s. That's one reason I mentioned Rochberg. It took courage for him to turn, as he did, towards melody and tonality.

Marcus Paus: It did. And the situation was definitely still there 20-odd years ago the modernist prejudice against traditional musical values still ruled the "academy.” So I felt somewhat ostracized. This undoubtedly played a part in shaping my musical personality as a "traditionalist," or should I perhaps say "anarcho-traditionalist.” I felt I needed to rebel against the narrow perspective I was being asked to conform to at the Academy.

Edward Green: I like that phrase: "anarcho-traditionalist." It's surprising, and a nice confutation of the idea that loving what's "traditional" inevitably means being dull, unimaginative - "conservative" in the bad sense of the word. So, yes, I admire that: joining the wild, unexpectedness of anarchism with the solidity of traditionalism.

Marcus Paus: Yes, the phrase I used about myself does put opposites together and I remember you talked a great deal about that at Manhattan School of Music: Eli Siegel, Aesthetic Realism, and the tension of opposites.

Edward Green: Yes, the oneness of opposites. Eli Siegel's great statement: "Every person is always trying to put together opposites in oneself."

Marcus Paus: Well, it's certainly true about me. And, you see, I always knew my inclination was to be a lyrical writer - which meant, of course, a love for the traditional. The music that I admired and hoped to emulate when I was in my teens, seemed to demand that I'd subject myself to a certain kind of rigorous training. And I was very lucky to have a great teacher, the Norwegian composer Trygve Madsen, who had a very practical approach to what could have easily been an overwhelming curriculum - since tradition is a deep and rich thing. Centuries of knowledge.

My background when I started studying with Madsen was really various strands of (more or less progressive) vernacular music, 
and I already had a fair grasp of history and theory, and a relatively well-developed ear. And perhaps I was lucky not to have had classical training up until that point. I played electric guitar, and so I had no innate fear of the great masters of the Western classical tradition, no pedestals on which to put them. My ears had simply drifted towards 20th century classical music and film music as I transitioned from performer to writer.

With Madsen, I studied counterpoint from the perspective of Bach's Inventions, Sinfonias and of course Das Wohltempertiertes Klavier. But also Shostakovich's op. $87-$ modeled, as you know, on the great Bach collection of preludes and fugues.

Through those two great contrapuntal collections, separated by well over 200 years, Madsen showed me the validity of technique, regardless of style or era. And I was invited to become inspired by these great models, rather than intimidated. I would write canons, inventions, fugues, and I would also bring in whatever I was working on, and he would critique these early efforts always from a performance perspective, sharing practical insights from his own experience as a working composer.

Edward Green: I'm glad you mentioned that. It's so important that composers learn not to work in the "abstract," but always with real performers in mind - always with the actual impact on other human beings both of creating the music, and hearing it. Too often, I've noticed, student composers get a quasimathematical idea for a work, and don't ask enough: will people enjoy playing this? Singing this? Listening to it?

Marcus Paus: Very true.

Edward Green: I met you, of course, quite a while back when you were doing graduate studies at Manhattan School of Music - after those years at the Norwegian Academy. Can you say what stood out for you at MSM? Were there professors who were particularly inspirational for you?

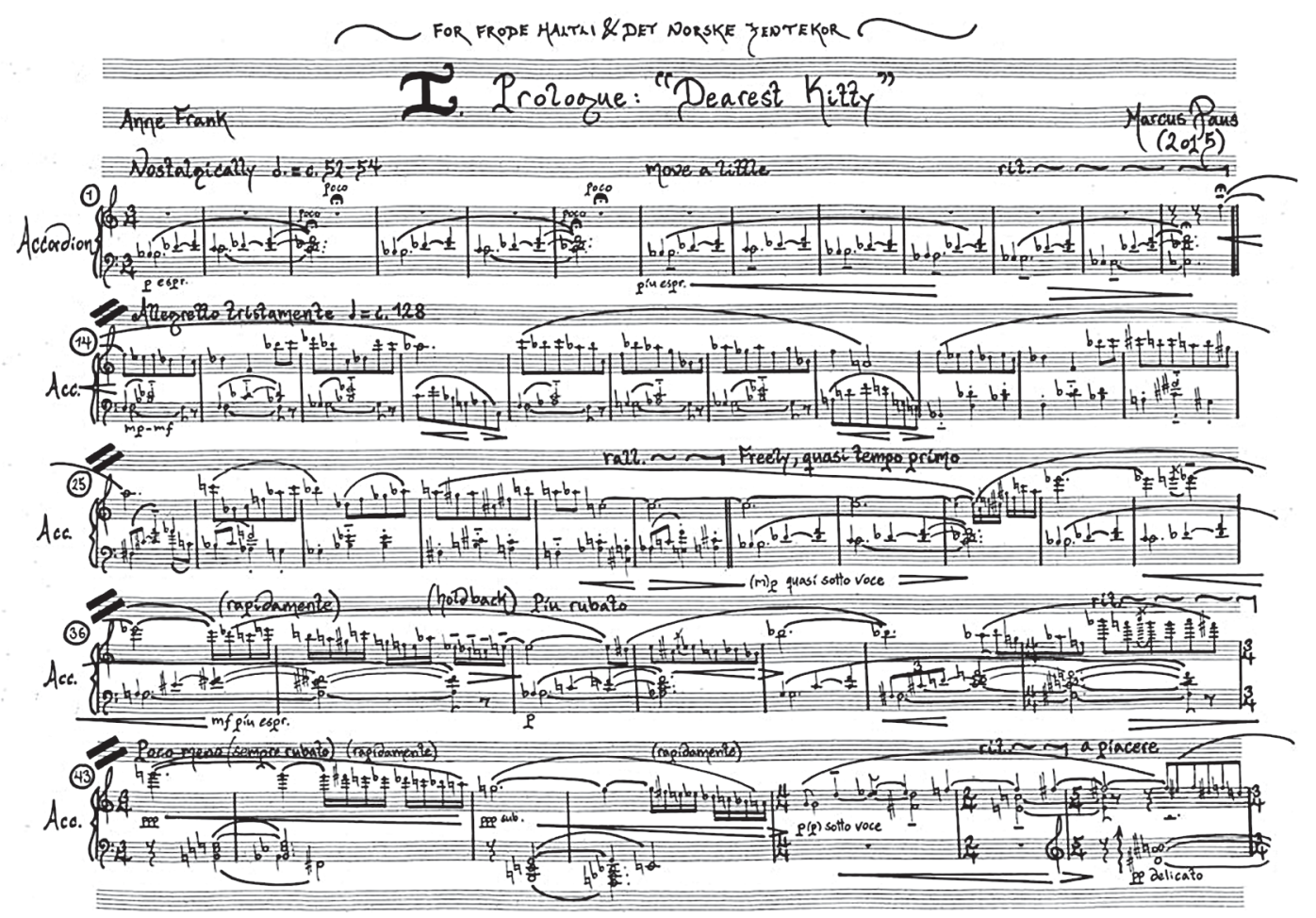

Photo 2. Manuscript of The Beauty That Still Remains -

A Cantata by Marcus Paus, Words of Anne Frank [photo credit: Norsk Musikforlag] 
Marcus Paus: Coming to MSM was a relief to me, for many reasons. What immediately stood out, was a general absence of ideology, and an appealingly pragmatic approach to craft. My reason for wanting to study in the US was my love for American contemporary composers such as John Williams, John Corigliano, Richard Danielpour, Christopher Rouse and others. To my mind, the entire classical-romantic tradition had been residing stateside since WWII; also, I do have to say, in Russia. Europe, as I said before, was largely trapped in a modernist/post-modernist cage. I was glad to escape!

At MSM I had the great good fortune to study with one of the people I mentioned earlier: Richard Danielpour. He was, as they say, my "major" teacher. And the lessons he taught me were important, and helped give further shape to, and even more impetus, as well, to my opinion that a composer should always write with the performer centrally in mind.

We'd have readings of new pieces at his studio, and he would comment on the score very much from a producer's point of view, focusing on the minutiae that would yield a better sound, and make the music project.

And I hope you will forgive me for also singling out your film scoring and songwriting classes, both of which continue to be part of how I think and feel about music drama and text setting.

Edward Green: OK, and thanks. It looks as if you couldn't leave it "unstated."

Marcus Paus: It feels important for me to state it. Not only in gratitude, but in recognition of the core underlying motif of these classes as I understood it: the idea again from Eli Siegel — that what happens in music "in the abstract" is inseparable from the "programmatic" power of music. It was his statement "In reality opposites are one; art shows this," that affected me - as you showed how the drama of opposites in a film scene, or in a set of lyrics, was what a composer needed to reflect in the music he brought to the film or song.

\section{https://youtu.be/7w2GQdRzdwo \\ Link to Marcus Paus' score for Andre Øvredal's film MORTAL}

Edward Green: Yes, I do think so. I think the ideal for any song is a full marriage of words and music; the ideal for a film scene being, very much related: a complete interpenetration of the visual and the auditory aspects of the film. And that leads me to say: I also remember you then as a ferocious advocate - in the good sense of both words - of the music of John Williams. If my memory serves me right, at the time you thought he was the greatest living composer. Am I remembering right? If so, is that still your opinion? And, in any event, can you tell us about the impact of Williams on you?

Marcus Paus: John Williams was my first orchestral love. And I do think the perfection with which he so often joined sight and sound in his film scores was the reason for that love. Let's face it: growing up in the 1980s meant having your childhood underscored by him!

Edward Green: I understand. It's paralleled to what I, and so many others, felt growing up in the 60's: having the Beatles as the soundtrack of your teenage years.

Marcus Paus: So, later - as my own musicality awakened and I began to think of myself as a "composer-in-training" - I rediscovered him. But now not just from an audience's perspective, a "fan's" perspective, but from a musician's perspective. The more I studied him, the more I was enthralled by his phenomenal technique, and the expressivity of his language. I certainly still revere him, and consider him one of the great composers of any century.

Edward Green: That's what I meant! What an advocate you still are for him; I never heard anyone else put him in quite that category: "of any century."

Marcus Paus: Yes, I sincerely feel it. And it's really a very considered opinion; I've tested it. On top of that, there's this surprising fact to consider: in the strangest of ways, he might also have come the 
closest of any composer to realizing the old Schoenbergian utopia that children of the future would be whistling 12-tone rows! Although not exactly 12-tone, "The Imperial March" and the main theme from Harry Potter are both decidedly 12-note. But more than an ear-opening "gateway drug," I think Williams has found a very satisfying way of embodying dissonance and avant-garde techniques within a larger tonal framework. That's the big achievement. Again, a making one of opposites, if you will.

Edward Green: Yes, and not just in a technical sense; it is a way of bringing together, in a unified sonic experience, the strange and the familiar - and these are big opposites in everyone's life to make sense of. And Eli Siegel lectured on them often; in fact, he said they were the central opposites which impelled the Romantic Era. I remember one lecture, very clearly, where he showed how that was so in the poetry of Wordsworth and Coleridgeand how Wordsworth generally began with the familiar, and showed the mystery there, while Coleridge often began with supernatural, strange subjects, but presented them so convincingly, they took on the feeling of "actual event," that is to say, the familiar.

Marcus Paus: That is very interesting! Especially since Williams is often described as a "Contemporary Romantic." It's also interesting to note just how much the sound of his scores has shaped our modern conception of what an orchestra can sound like, regardless of style. That makes him at the very least one of the most impactful composers of our time, and one of the most culturally relevant. What impresses me the most about him, though, is the humanity of his work, and his sense of purpose. There's something of a latter day Haydn about him. A man entirely in the service of his art form, and who feels no conflict between sincerity and craft.

Edward Green: And that is another - and very glorious - aspect of the opposites: the coming together of personality, untrammeled individuality, and what's impersonal - sheer knowledge, craft, technique. I agree, too, about

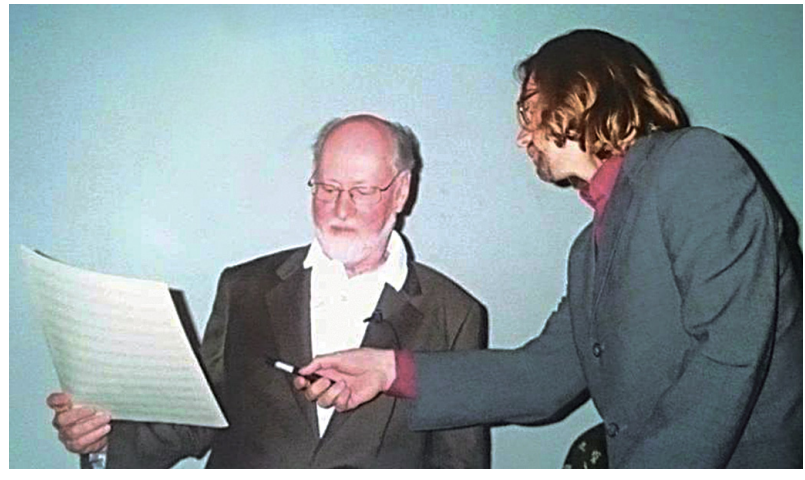

Photo 3. Marcus Paus with John Williams [photo credit: Aleks Ozelins]

the relation you make to Haydn: both men, it strikes me, have a beautiful humility in them; an awe about music, and its power to tell the truth about the world and human feeling.

Marcus Paus: Yes, I agree. And as far as I'm concerned John Williams - like Haydn - is musical nobility. By the way, do you know that I once met him?

Edward Green: No, I didn't. What were the circumstances?

Marcus Paus: It was in 2005 in Pittsfield, Massachusetts, at a Question-and-Answer event which was part of the Tanglewood Festival. It was a relatively short and sweet encounter. Afterwards, I had the chance to show him a set of variations I had written on a cryptogram of his name. He was very welcoming, very courteous, and (of course) as a young composer that moved me very much - that someone of his international stature was happy to take out the time to be interested in my work.

What I remember most vividly, though, wasn't so much about me; it was throughout that event - Williams's very genuine, almost deferential humility. He kept using every occasion to point away from his own work, and steer our attention towards other artists and composers. And there was his seemingly encyclopedic knowledge of repertoire, let alone of literature about music - all on casual display. I remember him, for example, recommending a book on Mendelssohn by Larry Todd, which I subsequently bought and read. 
Edward Green: That's a very impressive story; I'm glad to know it - and it does seem to go along with so many other stories about Williams. You're right in seeing a kind of real nobility in him: as a man, and as an artist.

While we're talking about composers who have inspired you, are there any other names - from any century - you'd like to mention, and say why?

Marcus Paus: I am a collector by nature, and in my younger days, whenever a composer or artist caught my attention, I would make a point of becoming acquainted with his or her entire oeuvre, or as much as I could find. As such, I went through infatuation upon infatuation. But as the years go by, I find my private pantheon populated by fewer and fewer deities. It's not that I don't want to find value wherever it truly is. But I don't want to confuse lesser value with greater value. That would be unjust to music.

Edward Green: I agree with that. Once we call everything "great," we can lose sight of just how much we can learn - and be moved by - what's truly great.

Marcus Paus: There are the great cornerstones, of course! And I know some of my personal feelings are a bit unorthodox. But I have to be candid: I never feel quite as comfortable with (or comforted by) Bach as with, say, Poulenc.

Edward Green: Surprising!

Marcus Paus: Yes, I imagine so. But for whatever reason, my greatest loves have been composers whose contributions may be slightly less titanic (although still formidable), but perhaps for that very reason all the more human. You mentioned the opposites of "personal" and "impersonal" before. I suppose I give a bit more weight to the "personal."

In any case, among the composers to have the most lasting impact on me I'll mention Ravel - for the exquisite beauty of his craftsmanship and the serenity and grace of his art, Shostakovich - for his sincerity and his sense of form, Poulenc - for the wistful charm and lyricism of his melodies, and John Williams - for his sense of stylistic synthesis and his profound musicality.

Edward Green: I think that's a unique quartet! But I can see, knowing something of your own music, why it would be. Now, on a slightly different tact: ICONI is, as you know, largely a Russian journal, and its readership is largely Russian at this moment. Being Scandinavian, there's a certain rich history culturally, and otherwise - between your part of Europe and Russia. Are there Russian composers who have particularly affected you? Russian performers?

Marcus Paus: Having already mentioned Shostakovich, I must add Prokofiev.

Edward Green: Yes, my own favorite 20th century Russian composer.

Marcus Paus: And also I need to point, in particular, to Rodion Shchedrin, whose technique is simply mindboggling. His contrapuntal writing is astounding, as are his orchestrations. A deeply original composer, and perhaps not as well-known as he should be (despite certainly having had an illustrious career).

Edward Green: I agree about that. For one thing, his Anna Karenina ballet is a powerful work.

Marcus Paus: Yes. He's also written several marvelous concerti for orchestra. And his Preludes \& Fugues, of course, as well as his Polyphonic Notebook.

Edward Green: Now, let's turn to another aspect of music. I know your father is a famous Norwegian songwriter and popular performer, and both you and your wife have worked in the field of Rock-and-Roll, as well (of course) as "classical music." How do you see the relation of pop or vernacular music and - for the lack of a better word - the classical tradition? Do you mingle these in your work? Or do you work in both fields, but largely keep them separate?

Marcus Paus: I think it would be almost impossible today not to in some way be informed by various kinds of vernacular music, given their omnipresence in our lives. I think of myself simply as a writer of music. My particular vantage point is music 
as a written language. This shapes how I think, how I hear, how I create. Although I don't make any effort to be eclectic, I will allow my musicality to be as promiscuous as it desires; I try not to censor my impulses, as long as they serve a greater purpose of expression.

\section{https://youtu.be/s TcSa2Mc64 \\ Link to 4th movement of Marcus Paus' Cello Sonata}

Edward Green: Do you collaborate often?

Marcus Paus: Her background also includes classical training, so she has this very unique aspect of being both singer/ songwriter and arranger. She writes all of her own arrangements, so we're working along more parallel lines than what one would perhaps imagine. She's also recently ventured into more classical terrain, writing choral and chamber pieces. I was invited to contribute a couple of guest arrangements on her last album, and I'm sure we'll continue to make guest appearances in each other's musical worlds.

Edward Green: Related to the previous question about "vernacular/pop" music but not quite the same - is how you see Norwegian folk music, and also the many streams of traditional music out there from other cultures: India, China, Korea, subSaharan Africa, Bali, etc. Have these played a role in your work?

Marcus Paus: Yes, certainly. And it began early on. As a teenager, while I was still only a performer, I was hugely interested in several types of traditional music, especially Bulgarian music. But I was also very taken by Indian, Persian and Pakistani traditions, and I spent a great deal of time learning the modalities, rhythms and ornaments of these traditions. When I was 18, I even got the chance to play a little with a Bulgarian wedding band while on holiday in Bulgaria. Some of the chamber pieces I wrote in my early 20s display the influence of Bulgarian music quite explicitly, such as my Lasûliansko Horo for violin and piano.

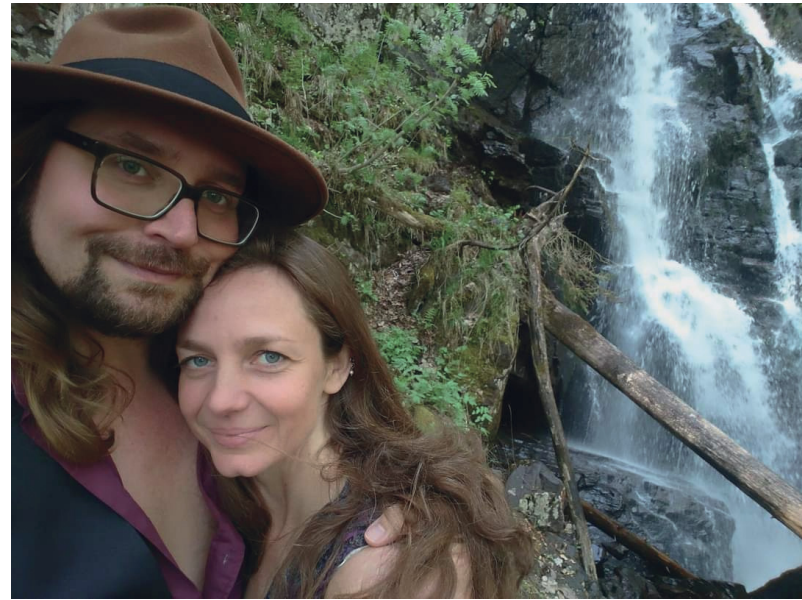

Photo 4. Marcus Paus and Tirill Mohn (Paus) [photo credit: Marcus Paus]

Some years ago, I had the privilege of writing the music for a dance production featuring Norwegian folk dancers and Chinese Kung Fu monks. Parts of this music was reshaped as A Portrait of Zhou, a concertino for flute and orchestra, in which I attempted to find a musical common ground between these traditions. The Norwegian folk musical element is probably more subliminal. It became more present as a stylistic trait in my music when I was living abroad during my 20s. Some of it undoubtedly comes from Grieg, and perhaps more directly from the Norwegian composer Geirr Tveitt, and has to do with a certain flavor of bimodality and extended tonality. In later years, I've found that all these impulses have become more integrated into my own language, rather than calling attention to themselves as topical seasoning.

Edward Green: You've written a great deal of vocal music - solo song, choral music, and opera. Plainly you love the relation of words and music. Can you tell the readers how you approach the setting of words?

Marcus Paus: Words are my passion. If I weren't a composer, I would probably have endeavored to become a poet or a writer. Perhaps my father, with his love for the relation of words and music, had something to do with this. In any case, simply put, when it comes to vocal literature, I set what I love, 
and what I cannot resist. Setting poetry is an urge. My goal is to have the music enhance the text so that a setting reveals upon listening what might otherwise only be gleaned through repeated readings.

I think of music as subtext and symbolism. When setting text, I'm wary of melisma, and distrustful of anything that obscures the words. Natural prosody is my guideline, and I try to adhere also to the form and dynamics of the poem. If I set a sonnet, I want the audience to feel the impact of its final stanzas (or couplet, if it's Shakespeare).

Edward Green: Brahms, as you know, felt very much the same way.

Marcus Paus: Yes, I've gathered that. I also think this is true about the best pop composers, too. Lennon and McCartney, certainly.

Edward Green: Speaking of the power of words, I gather you are actually in the "family line" of perhaps the greatest Norwegian author ever; in fact, the greatest Norwegian who has yet worked in any of the arts. I mean, of course, Henrik Ibsen. What are you? A great-great-grandson?

Marcus Paus: Hah! Almost: my greatgreat-grandfather was Ibsen's cousin.

Edward Green: So, I'm sure readers would be interested in what you might like to say about him and his art. For that matter, have you ever thought of making an opera out of any of his plays?

Marcus Paus: Growing up in Norway, Ibsen is easily taken for granted. But the older I get, the more strongly his works resonate with me. He was certainly one of the inventors of the modern mind. I actually started thinking about making an opera of Peer Gynt while still at MSM, and I already know how I'd solve it. It has to do with Solveig's final words, and making a lullaby of them that will serve as a lyrical undercurrent throughout the arc of the opera, only to have its true significance revealed as the opera closes. Lullaby as redemption (and I've already set it).

Edward Green: Well, I hope you get to write that opera! Recently I read Brand, and I thought it had opera potential, too. But the poetry, I imagine, is much stronger in the original than in the English translation. So it would be a job for a Norwegian.

Marcus Paus: Well, it's worth thinking about.

Edward Green: I'd like to talk for a moment about some of your chamber music. I was very taken by the fact that each of your string quartets is inspired by the work of a visual artist. Of course, everyone knows about Mussorgsky and how Hartmann inspired his Pictures at an Exhibition. And there are other examples, for sure, where a composer wants to honor a particular artist. I'm thinking, for example, of my favorite piece of Morton Feldman: his Rothko Chapel. So any comments on all this?

Marcus Paus: Art is another great passion of mine. And as with poetry, I find that art will sometimes prompt a musical response. I've had several collaborations with visual artists, and most prominently the Swedish painter Christopher Rådlund, with whom I've worked for almost 20 years now.

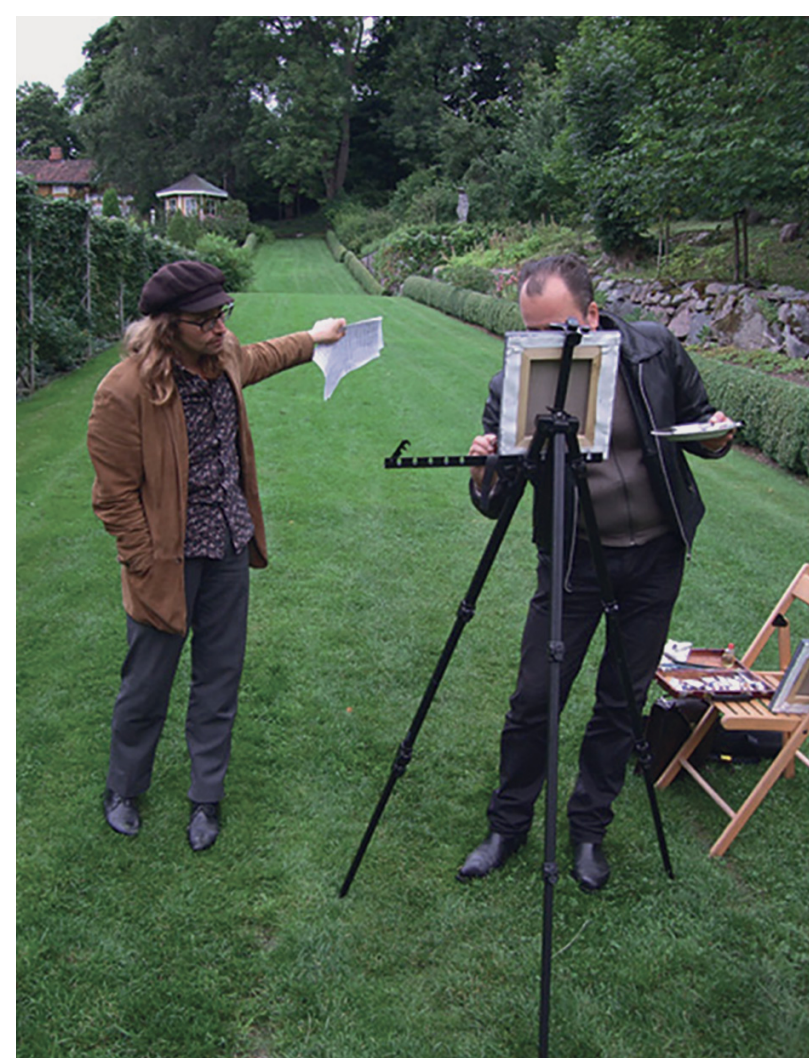

Photo 5. Marcus Paus with Christopher Rådlund [photo credit: The Beauty That Still Remains] 
Edward Green: To me, a crucial thing for any composer is to have a philosophic, or even a religious, viewpoint that he or she is proud of, and which impels the music. My own, as you know, is the perspective of Aesthetic Realism, which I learned from its founder, Eli Siegel - whom I had the honor to study with. I do passionately think that there is no greater, or more precise, explanation of the relation of Art and Life than his statement: "All beauty is a making one of opposites, and the making one of opposites is what we are going after in ourselves."

To me, it's simply logical; inevitable: I just don't think important music can come from a shallow or a narrow world-view. So, can you say what you feel, in an over-arching way, inspires your music? What it is you hope your music truly is fair to?

Marcus Paus: I wholeheartedly agree with what you are saying, and also your assessment as to the source of the best in music. And I love the way you phrase these questions. What I hope to be truly fair to, is music as an expression of life and reality as I feel and experience it. I try to respond as sincerely, beautifully and completely as I can. I find that my music changes as I change, and I try to allow these changes without letting my ego interfere. Another way of putting it, is to say that I aim to be vulnerable. As for overarching ideas, I consider myself a humanist first and foremost. This tends to inform what kind of projects I'm drawn to, and how I approach them.

Edward Green: Related to the last question is its earthy parallel: a composer's political and social commitment. Are there matters of this kind that you are passionate about? And has that passion taken musical form?

Marcus Paus: I would consider myself an anarchically inclined social democrat. I am liberal and left-leaning in most questions, but beyond a left/right perspective, I'm concerned about non-authoritarian/ authoritarian tendencies, which zigzag across the entire political spectrum. One of the pieces I'm most proud to have written is The Beauty That Still Remains - a choral composition based on the Anne Frank Diaries.

\section{https://youtu.be/zUOhWNJ_npI \\ Link to "Epilogue" of The Beauty That Still Remains}

I think the greatness of any society should be measured by the dignity it affords its least privileged citizens. I also think societies are healthy only to the extent which they allow anarchic tendencies. As an anti-authoritarian with a social conscience, it's difficult not to be alarmed by the present state of affairs. There's a sense of fatigue that creeps into everything as real agendas are supplanted by the fake news and alternative facts so beloved by right-wing politicians: in America and, I'm sorry to say, also here in Europe. It is terrible to see how real social injustice gets obscured by narcissistic crusades.

I fear we've become post-cultural, postpolitical, post-everything. It's not an easy perspective to write from. I actually wrote a piece early on during lockdown, entitled Good Vibes in Bad Times. It's a piece for mezzo-soprano and vibraphone, and it sets a collection of "poems" by Donald Trump (assembled by Robert Sears). But more than being merely a satirical take on Trump (which, of course, it obviously is), these texts offer a humanizing perspective, allowing us to take pity where reality otherwise leaves little room for it.

Edward Green: Yes, every twisted mind begins untwisted. One can't imagine a newborn baby hating truth the way, later in life, a person can; certainly, a person like Trump. So, if I understand you right, I agree: we should hate evil and pointedly satirize it (including wherever we see it in ourselves) - without losing sight of the great pity that any mind would stray so far from where it began. It is a terrible, a pitiable thing: the way we can outrage our very deepest selves - which are built for truth, kindness, and beauty.

Marcus Paus: Yes. Agreed.

Edward Green: Contempt, Eli Siegel once said, is the great temptation in every life. In 
fact, our greatest danger: to think we will be for ourselves by making less of the outside world. He explained that contempt is the "lessening of what's different from ourselves as a means of self-increase, as we see it." It's false seeing, however! The value of things and of people doesn't depend on whether we decide to "give them their due," or not. The value simply is there! In fact, one can say and I learned this from him - that both Art and Science are motivated by the passionate desire to see what reality truly has in it, and to value it.

Marcus Paus: Yes - I've felt that as I compose: the feeling of "discovery." of finding beauty where it wasn't seen before. It's really an honor to try to convey that sense of discovery to audiences.

Edward Green: It is! And I learned from Aesthetic Realism that everyone's deepest desire is to like the world on an honest basis and that by showing there is much, much more beauty and meaning in the world than we ordinarily observe, art shows the way.

Marcus Paus: I think that's a beautiful perspective. And deeply true.

Edward Green: It really does come down to this: What are we, individually, and also as a society, going to prefer - the art way or the contempt way?

Marcus Paus: I guess my little Trumppiece is a modest way of addressing just that. I hope it helps!

Edward Green: I hope so, too! OKcircling around now: I started, with the first question, saying something about how you stand out, in a large degree, from most other composers ofyour generation. But one doesn't have to agree, in terms of "musical language," with someone to admire their work. I can think, for example, of many composers I care for deeply who work in very different styles, and in very different idioms, from me. So who among composers, say between ages 30 and 50 (your generation, roughly), do you most admire? And, of course, why!

Marcus Paus: I'm tremendously excited about so many composers in my generation! I will mention a handful of those of my colleagues whose works have touched and impressed me recently. Let me start by mentioning two of my colleagues from MSM, Christopher Cerrone and Anna Clyne.

Edward Green: Yes, I remember them both. Fondly.

Marcus Paus: And each of them already has a high-profile career. Cerrone rose to prominence with his opera Invisible Cities and a number of vocal works. He is a great setter of poetry, and also a wonderful orchestrator. His music can perhaps be described as "Feldmanesque," but with indie pop-sensibilities. I recently heard Anna Clyne's cello concerto - titled Dance; I think it's one of the finest of its kind. (Cello concerti, as you know, are not easy to write!)

Anna's music is urban, playful, gritty and lyrical, and imbued with genuine warmth. Keeping it stateside (although Anna is from UK), I've been very impressed by Andrew Norman, who writes dazzlingly brilliant orchestral music. A phenomenally gifted orchestrator, he writes music that is vibrant, energized and overwhelmingly colorful. I recently heard some works by Akshaya Tucker, an American composer/cellist/ dancer/choreographer deeply influenced by Indian classical music, and found her music convincing, moving and beautiful. Two other composers I should mention are Octavio Vasquez and Lera Auerbach. Both are more traditionally inclined than the composers previously mentioned, but they're every bit as original, composing new music of great craftsmanship, integrity and beauty.

Among European composers, I'd like to mention Vito Palumbo, a fabulous Italian composer who writes with incredible virtuosity, detail and musicality. He has taken the techniques of Ligeti and Lachenmann, and made a kind of music that flows with impressionistic gossamer grace. Finally two Nordic composers, Sauli Zinoviev and Benjamin Staern. Zinoviev writes music in a kind of cinematic, post-Sibelius style. Staern is also deeply rooted in tradition, and has written operas as well as several highly successful orchestral and concertante works, 
in a language that juxtaposes modernist jargon with a more American flavor of orchestration. Neo-Stravinskyan, perhaps.

Edward Green: Thanks for that rich and very detailed answer. I lost count! Something like a dozen names there; lots of people for me (and the readers of ICONI) to get to know or if we do know something of them, to dig deeper. All of which is wonderful.

Now, speaking of richness: everyone who knows you knows how astonishingly productive you are. You've already written a vast catalogue of music. Including concerti. I know your Timpani Concerto made quite an impression at its premiere.

Marcus Paus: Thank you. I enjoyed composing it a great deal.

\section{https://youtu.be/fNU-hFR7jbE Link to the Timpani Concerto of Marcus Paus}

Edward Green: Still, I imagine you don't spend every waking hour writing music! Brahms, for example, read a very great deal. Schoenberg (and others) painted. Mahler, along with so much else, simply couldn't do without adequate time in nature. (Beethoven, too). Prokofiev played professional-level chess. And I could go on. So - in addition to music, what are your greatest loves?

Marcus Paus: As I've already mentioned, two of my great passions in life are poetry and art, and I spend a lot of time exploring both (often, I'll admit, with musical ulterior motifs). I am also an avid film enthusiast. I actually don't spend as much time as I used to listening to music (probably as a consequence of my writing hours being as long as they are), and most concerts I attend are performances of my own works. I enjoy socializing when I can, and otherwise I am blessed to reside in rather rustic surroundings, fjordside and forested, in which my wife and I go for walks most days.

Edward Green: And now, the concluding question: for young composers reading this interview, what wisdom would you like most to impart?
Marcus Paus: My main advice is not to worry too much. Fear is a given for all of us. Own your insecurities and imperfections; they will ultimately prove to be your greatest assets. From a technical point of view: Always write with a performer in mind, preferably someone specific. Get your music performed at any cost. That's when you learn. Be kind and generous with your performers always, and be forgiving of your own efforts.

More advice: rather than contrive to be original, be true to what you like. Study the music that moves and interests you, and try to figure out what makes it work, and why. There's always logic behind true emotion: find it! And always root for your colleagues. Your only enemies are ego and bitterness, and overcoming them will require an active effort. Also (especially when starting out, but it's never a bad idea): Write solo works and duos to cultivate your preferences within single line and two-part writing. You will learn a lot, also about your own language, and your technique and grasp of line, harmony, texture and form will grow, and as a bonus, you will have a catalog of works that are easy to program.

Edward Green: Good advice! And thanks for this engaging interview.

Marcus Paus: My great pleasure; thanks for having me! 
About the author:

Edward Green, Ph.D. (New York University), Composer,

Professor in the Department of Music History, Manhattan School of Music, (10027, New York, United States of America)

ORCID: 0000-0002-7643-1187, edgreenmusic@gmail.com

Об авторе:

Эдвард Грин, доктор философии (Нью-Йоркский университет), композитор, профессор кафедры истории музыки Манхэттенской школы музыки (10027, г. Нью-Йорк, Соединенные Штаты Америки),

ORCID: 0000-0002-7643-1187, edgreenmusic@gmail.com

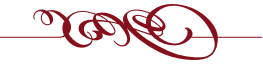

